\title{
Prevalence of asymptomatic bacteriuria and its consequences in pregnancy in a rural community of Bangladesh
}

\author{
M. Anayet Ullah ${ }^{1}$, A. Barman², M.A. Siddique ${ }^{3}$ and A.K.M.E. Haque ${ }^{1}$ \\ ${ }^{1}$ Department of Community Medicine, Rajshahi Medical College, Rajshahi, Bangladesh; \\ ${ }^{2}$ Department of Medical Education, University of Sains Maslaysia, Kelantan, Malaysia; \\ ${ }^{3}$ Department of Microbiology,Rajshahi Medical College, Rajshahi, Bangladesh. \\ e-mail: ullahanayet@yahoo.com (MAU)
}

\begin{abstract}
This was a cross-sectional followed by cohort type of study conducted among the pregnant mothers of second trimester in the rural areas of Rajshahi district. Initially 1800 pregnant mothers of second trimester were selected from 18 unions applying 2-stage random sampling. A total of 216 pregnant mothers with asymptomatic bacteriuria were paired among the rest of the healthy pregnant mothers (without bacteriuria) on the basis of age, gravida and economic status for cohort study to relate asymptomatic bacteriuria with the incidence of symptomatic bacteriuria, hypertensive disorders in pregnancy (HDP) and pre-term delivery. The matched paired pregnant mothers were followed monthly interval up to delivery. The prevalence of asymptomatic bacteriuria was $12 \%$ among the pregnant mothers in rural Rajshahi. E.Coli was the commonest causative agent of both asymptomatic and symptomatic bacteriuria. The results of this study suggest that asymptomatic bacteriuria were more prone to develop symptomatic bacteriuria, hypertensive disorders in pregnancy and pre-term delivery than that of the healthy mothers (without bacteriuria). Screening of bacteriuria in pregnancy and proper treatment must be considered as an essential part of antenatal care in this rural community.
\end{abstract}

\section{Introduction}

Urinary tract infection (UTI) is one of the most common diseases encountered in clinical practice today. Urinary tract infection is not only common but the range of clinical effect varies from asymptomatic bacteriuria to acute pyelonephritis ${ }^{1}$. Urinary tract infection is the common of all bacterial infections, affecting human beings throughout their life span especially in women ${ }^{2}$. Nearly $50 \%$ of all women develop symptoms of urinary tract infection at some stage during their life. Urinary tract infection account for more than 7 million visits to physicians and necessitate over 1 million hospital admissions in USA annually ${ }^{2}$.

The urinary tract undergoes profound physiological and anatomical changes during pregnancy facilitating the development of bacteriuria both symptomatic and asymptomatic in women ${ }^{3}$. Symptomatic bacteriuria is an iceberg of total bacteriuria. Pregnancy is a provocation for the asymptomatic to become symptomatic ${ }^{4}$. About $10 \%$ of those with asymptomatic bacteriuria develop symptomatic bacteriuria during pregnancy $^{5}$. Incidence of bacteriuria during pregnancy is also very common in Bangladesh $^{3}$. Begum (1992) ${ }^{3}$ in her study found that $10 \%$ of pregnant women attended in antenatal clinic of Mymensingh Medical College had symptomatic urinary tract infection. In another study by Khatun et al. $(1985)^{6}$ revealed that $30 \%$ of clinically healthy pregnant women had asymptomatic bacteriuria. Symptomatic bacteriuria poses no problems because of easy in diagnosis and treatment due to its overt symptoms. But asymptomatic bacteriuria is difficult to diagnose and it is more common in pregnant women than non-pregnant women ${ }^{6}$. But asymptomatic bacteriuria especially important in pregnancy because $30-40 \%$ of untreated pregnant women with asymptomatic bacteriuria develop acute pyelonephritis at the late pregnancy ${ }^{7,8}$. Also there is evidence that when there is no symptom, untreated bacteriuria in pregnancy may lead to less favorable pregnancy outcomes and complications like preterm delivery, low birth weight, pre-eclamptic toxemia and anemia of pregnancy ${ }^{7}, 9$. 
The present study was undertaken to estimate the prevalence of asymptomatic bacteriuria in pregnancy; its causative agents and their sensitivity pattern, and its consequences in pregnancy in the rural community.

\section{Materials and Methods}

Selection of participants and follow-up: The study was conducted in the rural areas of Rajshahi district. The pregnant mothers of second trimester of this area were constituted the study population. The number of the study population was 10,400 . A total of 1800 pregnant mothers of second trimester were screened to estimate the prevalence of asymptomatic bacteriuria and select the asymptomatic bacteriuric group and their controls for follow up. The total number of mothers for screening was estimated on the basis of total study population and probable proportion of attribute (asymptomatic bacteriuria) of the rural areas after applying design effect of 2 . These 1,800 mothers were selected by 2 stage cluster sampling. In the first stage, 18 unions, 2 from each of 9 Upazillas, were selected by random sampling method. Then every subsequent house, starting from the house closest to the Union Parishad Office, with a mother of second trimester was chosen to complete the total number of 100 from each Union. The study was done in 2 phases. In first phase, the selected 1,800 pregnant mothers of second trimester were screened, either they have asymptomatic bacteriuria or not. Asymptomatic bacteriuria was defined as the presence of $\geq 10^{5} / \mathrm{ml}$ colonies of the same bacterial species in two consecutive midstream urine without any symptom of urinary tract infection. After identifying the asymptomatic bacteriuric and non bacteriuric (healthy) mothers, the study (asymptomatic bacteriuric mothers) and control (healthy) groups were selected on the basis of the inclusion and exclusion criteria for the follow up. Criteria for inclusion of the subjects (both groups) in this study were, as follows: had blood pressure within normal limit and made a pair, each from both the groups by individual matching on the basis of age ( \pm 2 years), gravida (primigravida, multigravida and Grand multigravida) and economic status (rich, middle class and poor). Exclusion criteria of the pregnant mothers for both the groups were as follows: had superimposed hypertensive disorders or chronic hypertension or a history of renal, cardiovascular, metabolic and liver diseases. A total 216 asymptomatic bacteriuric mothers were selected as study group. Equal numbers of the healthy mothers were selected as the control group among the identified healthy mothers (without bacteriuria either symptomatic or asymptomatic) in this study for the follow up. There after both the groups, asymptomatic bacteriuric and healthy mothers, were followed up by monthly interval up to delivery. They were also visited on ad hoc basis, when needed. At each visit they were interviewed and examined thoroughly and had urine test done irrespective of their complaints for bacteriuria, toxemia of pregnancy and drugs taken by the mothers. Before selection as a study subject, informed written consent had taken from the every volunteer.

Specimen collection: On each visit, two consecutive midstream clean catch urine samples, one on the day of the visit and another on the next day of the visit, were collected in a sterile wide mouth test tube with aseptic precaution. The dip slide was immersed in the collected urine for few second. After that the excess urine was drained off from the slide by contact it with the wall of the urine test tube. The slide was then returned into dip slide container (outfit) and cap screwed tightly. The mothers were individually instructed about the technique for collecting clean voided midstream urine specimens. All the slides were sent to the laboratory and processed on the same day. Dip stick test for proteinuria was performed on the first day of specimen on each visit at the spot. All laboratory testing was performed in the pathology department of Rajshahi Medical College by medical laboratory technicians.

Laboratory techniques: In the laboratory the immersed dip slides were incubated at $37^{0} \mathrm{C}$ for 24 hrs. The viable bacterial colony count was estimated by commercial supplied dip slide's charts. Colony counts equal to or more than $10^{5} / \mathrm{ml}$ was considered as significant growth. Pure growths were identified and sub-cultured in an appropriate media. Then identification (biochemical) test was done for the species and sensitivity test was carried and using traditional stroke method. For the test of proteinuria, the end of the reagent strip was dipped in the fresh urine for approximately 1 second and shaken off by tapping the strip on the side of the container. After 30 to 60 seconds the test strip was compared with the color scale. Color range from yellow for "negative" and through yellow-green and green blue for "positive". The laboratory technicians were supervised by an assistant professor of the department, who was one of the co-investigators of the study.

Data analysis: Data were analyzed by computer using SPSS for windows. The prevalence of asymptomatic bacteriuria was calculated by dividing the total number of cultures with evidence of asymptomatic bacteriuria by the total number of pregnant mothers screened for selection of the follow 
up groups. Associations between variables were conducted applying Chi-square test. Relative risks of pregnant mothers with asymptomatic bacteriuria to develop symptomatic bacteriuria, hypertensive disorder in pregnancy (HDP) and premature delivery, with $95 \%$ confidence interval were measured.

\section{Results}

Of the 1,800 pregnant mothers screened in this study, 216 (12\%) had asymptomatic bacteriuria. The commonest organism causing bacteriuria both asymptomatic and symptomatic was Escherichia coli. The prevalence of different types of causative organism in both types of bacteriuria was more or less same (Table 1).

Table 1: Causative agents of bacteriuria in rural pregnant mothers

\begin{tabular}{lcc}
\hline Causative agents & \multicolumn{2}{c}{ Number of bacteriuria cases } \\
\cline { 2 - 3 } & Asymptomatic & Symptomatic \\
\hline Escherichia coli & 156 & 164 \\
$\begin{array}{l}\text { Staphylococcus and } \\
\text { Saphrophyticus }\end{array}$ & 44 & 40 \\
Klebsiella & 10 & 8 \\
Proteus & 6 & 2 \\
\hline
\end{tabular}

The sensitivity pattern of the isolated organisms revealed that all were sensitive to ciprofloxacin at very high percentage (Table II).

Tetracycline, nitrofurantoin, cephalexin and nalidixic acid were moderately sensitive to all the isolates ranging 42 to $78 \%$ with exception of tetracycline to Proteus and cephalexin to Klebsiella. The isolated

Table II: Sensitivity pattern of organisms causing bacteriuria in the rural pregnant mothers

\begin{tabular}{lllll}
\hline $\begin{array}{l}\text { Antimicrobial } \\
\text { drug }\end{array}$ & \multicolumn{4}{c}{ Causative bacteria } \\
\cline { 2 - 5 } & $\begin{array}{l}\text { E.coli } \\
\text { (n=320) }\end{array}$ & $\begin{array}{l}\text { Staph. } \\
\text { Saphro. } \\
(\mathbf{n = 8 4})\end{array}$ & $\begin{array}{l}\text { Klebsiella } \\
(\mathbf{n = 1 8})\end{array}$ & $\begin{array}{l}\text { Proteus } \\
(\mathbf{n}=\mathbf{8})\end{array}$ \\
\hline Ciprofloxacin & $97.5 \%$ & $92.9 \%$ & $100.0 \%$ & $100.0 \%$ \\
Tetracycline & $61.9 \%$ & $71.4 \%$ & $55.6 \%$ & $25.0 \%$ \\
Amoxicillin & $46.9 \%$ & $59.5 \%$ & $44.4 \%$ & $50.0 \%$ \\
Nitrofurantoin & $50.0 \%$ & $47.6 \%$ & $77.8 \%$ & $75.0 \%$ \\
Cephalexin & $45.6 \%$ & $69.0 \%$ & $27.7 \%$ & $50.0 \%$ \\
Nalidixic Acid & $41.9 \%$ & $52.4 \%$ & $66.7 \%$ & $75.0 \%$ \\
Co-trimoxazole & $30.6 \%$ & $33.3 \%$ & $11.1 \%$ & $25.0 \%$ \\
\hline
\end{tabular}

organisms showed higher resistance to commonly used and comparatively old drugs namely amoxycillin and co-trimoxazole. The mothers with persistent asymptomatic bacteriuria during their pregnancy had more than three times risk $(\mathrm{RR}=3.8$ with 95\% confidence interval 1.82-6.53) to develop symptomatic bacteriuria than that of the healthy (without asymptomatic bacteriuria) mothers. Other adverse outcomes of persistent asymptomatic bacteriuria during pregnancy were HDP and premature delivery. But after excluding the HDP cases and their pair from analysis, premature delivery was not identified significantly as an adverse out come of asymptomatic bacteriuria during pregnancy (Table III).

Out of 62 pregnant mothers having HDP, 34 (54\%) delivered premature babies. But it was much lower $(2.0 .8 \%)(\mathrm{p}=0.000)$ among the mothers without HDP. The relative risk of premature delivery among the pregnant mothers having HDP was 2.64 (95\% CI 1.93-3.60) than those mothers without HDP (Table IV).

Table III: Comparison of the proportions of adverse outcomes among the asymptomatic bacteriuric and healthy mothers during pregnancy

\begin{tabular}{|c|c|c|c|c|}
\hline Adverse outcome & $\begin{array}{l}\text { Asymptomatic bacteriuric } \\
\text { mothers \% (n) }\end{array}$ & $\begin{array}{l}\text { Healthy mothers } \\
\% \text { (n) }\end{array}$ & Relative risk (95\% CI) & P Value \\
\hline Symptomatic bacteriuria & $20.00(38 / 190)$ & $5.30(10 / 190)$ & $3.8(1.82-6.53)$ & 0.000 \\
\hline $\begin{array}{l}\text { Hypertensive disorders in } \\
\text { pregnancy (HDP) }^{\mathrm{a}}\end{array}$ & $14.90(20 / 134)$ & $6.00(8 / 134)$ & $2.5(1.44-5.47)$ & 0.013 \\
\hline Premature delivery ${ }^{\mathrm{b}}$ & $32.80(44 / 134)$ & $17.90(24 / 134)$ & $1.83(1.18-2.83)$ & 0.004 \\
\hline Premature delivery ${ }^{\mathrm{c}}$ & $18.20(20 / 108)$ & $10.20(11 / 108)$ & $1.81(0.91-3.60)$ & 0.06 \\
\hline
\end{tabular}

${ }^{a}$ Excluded the changed health status mothers with their pairs (either from asymptomatic to symptomatic or healthy or from healthy to asymptomatic or symptomatic); ${ }^{\mathrm{b}}$ Included HDP cases with their pairs; ${ }^{\mathrm{c}}$ Excluded HDP cases with their pairs.

Table IV: Hypertensive disorders in pregnancy (HDP) and premature delivery

\begin{tabular}{ll}
\hline HDP & Time of delivery \\
\hline
\end{tabular}

\begin{tabular}{lcc}
\hline & $\begin{array}{c}\text { Premature } \\
\mathrm{n}(\%)\end{array}$ & $\begin{array}{c}\text { Mature } \\
\mathrm{n}(\%)\end{array}$ \\
\hline With HDP & $34(54.8)$ & $28(45.2)$
\end{tabular}


Without HDP

$66(20.8)$

$252(79.2)$

$\chi^{2}=31.08 ; \mathrm{p}=0.000$; Relative Risk $=2.64$ (1.93 to 3.60$)$

\section{Discussion}

Urinary tract infections are remarkably common in women. Some $20 \%$ women in the age range 20-65 years suffer from at least one attack per year, $50 \%$ develop a urinary tract infections within their life time ${ }^{10}$. Not surprisingly infections of the urinary tract are the most common bacterial infections encountered during pregnancy. These can be both symptomatic and asymptomatic. Ten percent of pregnant women attended in an antenatal clinic had symptomatic urinary tract infections ${ }^{4}$. In another study by Khatun et al. (1985) of clinically healthy pregnant women had asymptomatic bacteriuria. Findings of the present community based study indicate that the bacteriuria in pregnancy both symptomatic and asymptomatic is also a major health problem in rural Rajshahi.

Observed from this study that E. Coli was the commonest pathogen responsible for bacteriuria. It is consistent with the findings of Rahman et al. (1990) ${ }^{11}$ and Ahmed et al. (1996) ${ }^{12}$. The findings of the study show that staphylococcus Saphrophyticus, which was formerly believed to be normal commensal, was recognized as the second most common pathogen accounting overall $19.5 \%$ of bacteriuria in this rural community. It corresponds with the findings of Ahmed et al. (1999) ${ }^{13}$.

Like the other studies ${ }^{10,13}$, the findings of the study also indicate that ciprofloxacin is highly effective to the urinary pathogens. It may be due to less use of Ciprofloxacin in the rural community since it is comparatively a newer introduction and also costly.

Rahman et al. ${ }^{11}$ in 1990 in their study observed that urinary pathogens at very high percentage ranging 75 to $100 \%$ were sensitive to cephalexin, nitrofurantoin and nalidixic and ranging from 50 to $100 \%$ were sensitive to co-trimoxazole in non diabetic patients. The findings of this study did not consistent with the findings of Rahman et al. This fact indicates that urinary pathogens became resistant day by day to the commonly used antibiotics in our country. This may be due to wide spread and indiscriminate use of the drugs.

There are many studies ${ }^{10,14-16}$ that link so many pregnancy complications like hypertensive disorders in pregnancy, low birth weight, premature with symptomatic bacteriuria. More over, for the last two decades, asymptomatic bacteriuria has also been identified as a risk factor of similar pregnancy complications $^{10}$. The results of the present study also agree with these findings.

The association between asymptomatic bacteriuria and pregnancy complication especially prematurity is out of question, it is now established fact ${ }^{7-9}$. But the mechanism is not well defined to the researchers. Several investigators have observed a high incidence of pyelonephrities in bacteriuric pregnant mothers ${ }^{7,8}$. It is convincing that the effect of urinary tract infection on premature labor could be indirectly mediated by antenatal maternal HDP. It is also plausible that urinary tract infection affects premature labor directly, through the development of ammonities. It has been previously suggested that bacterial infection of the amniotic fluid is a risk factor for premature delivery ${ }^{17,}{ }^{18}$. Another hypothesis contends that bacterial enzymes such as collagenase may weaken the fetal membranes and predispose them to premature rupture ${ }^{19}$. The results of the present study support the first one, because the association between asymptomatic bacteriuria and premature labor became insignificant when the mothers with HDP and their pairs were excluded from the analysis.

In conclusion, persistent asymptomatic bacteriuria in pregnancy causes different types of serious complications like pyelonephritis, HDP, low birth weight, premature labor, anemia etc, which are the leading causes of high maternal and infant morbidity and mortality in Bangladesh ${ }^{20-24}$. The unwanted sufferings of the pregnant mothers and their offspring could easily be prevented by early screening and treatment of asymptomatic bacteriuria in pregnancy. Screening of bacteriuria in pregnancy must be considered as an essential part of antenatal care.

\section{Acknowledgement}

We would like to express our gratitude to Bangladesh Medical Research Council authority for sponsoring this study.

\section{Authors' contribution}

MAU: Key person of this study and involved from the preparation of proposal to manuscript writing

AB: proposal writing up to submitting report to BMRC

MAS: from the proposal writing up to submitting report to BMRC, and supervised the laboratory works

AKMEH: Data analysis and report and article writing.

\section{References}

1. Ahmed S, Rashid HU. Urinary tract infection in adults: A review. Bangladesh Renal J. 1996; 15: 23-31.

2 Patton JP, Nash DB, Abrutyn E. Urinary tract infection: economic consideration. Med Clin North Am. 1991; 75: 


\section{5-513.}

3 Begum N. Clinical profile of urinary tract infection in pregnancy. Mymensingh Med J. 1992; 1: 6-10.

4 Doland I. Practical obstetric problems. $5^{\text {th }}$ ed. London, Lloyd-luke Ltd., 1979.

5 Bailey RR Urinary tract infection. Can Ded Assoc. 1972; 107: 315-30.

6 Khatun AK, Rashid H, Chowdhury TA. Prevalence of urinary tract infection in pregnancy. J Bangladesh Coll Phys Surg. 1985; 2: 6-10

7 Joseph KS, Brahmadathan KN, Abraham S, Joseph A.Detecting bacteriuria ia a primary maternal and child health care program. Bri Med J. 1988; 296: 906-7.

8 Turner AN, Savill J, Stewart LH, Cumming A. Kidney and genitourinary disease. In: Davidson's Principles and practice of medicine. Haslett C, Chilvers ER, Boon NA, Colledge NR (eds). $19^{\text {th }}$ ed. Edinburgh, Churchill Livingstone, 2002, pp 575-639.

9 Roony C. Antenatal care and maternal health: How effective is it? Maternal Health and Safe Motherhood Programme, Division of Family Health, World Health Organization, 1992.

10 Gilstrap LC, Leveno KJ, Cunningham FG, Whalley PJ, Roark ML. Renal infection and pregnancy outcome. Am J Obstet Gynecol. 1981; 141: 709-16.

11 Rahman T, Haque F, Begum J, Khan IH. Urinary tract infection in diabetic and non-diabetic patients. A comparative study. Bangladesh Renal J. 1990; 9: 8-12.

12 Ahmed I, Siddique MA, Rahman MM, Ali MS, Nessa J, Alam ABMM. Bacterial etiology and antimicrobial susceptibility pattern of suspected UTI cases. Mymensingh Med J. 1996; 5: 86-90.

13 Ahmed S, Jahan RA, Alam E. Bacteriologic etiology and sensitivity pattern of different drugs in urinary tract infection in adult. Bangladesh Renal J. 1999; 18: 9-12.
14 Truck M, Goffe BS, Petersdrof RG. Bacteriuria of pregnancy: Relation to Socioeconomic factors. N Engl J Med. 1966; 266: 857-60.

15 Sever JL, Ellenberg JH, Edmonds D. Urinary tract infections during pregnancy: Maternal and pediatric findings. In: Infections of the urinary tract. Kass $\mathrm{EH}$, Brumfitt W (eds). Chicago, University of Chicago Press, 1975, pp. 129-21.

16 Kass EH, Zinner SH. Bateriuria and pyelonephritis in pregnancy. In: Obstetric and perinatal infections. Charless D, Finland M (eds). Philadelphia, Lea \& Febiger, 1973, pp 407-46.

17 Chellam VG, Rushton DI. Chorioaminities and funiculities in the placenta s of birth weighting less than 2.5 kg. Br J Obstet Gynecol. 1985; 92: 808-14.

18 Guzick DS, Winn K. Association of chorioaminities with pre-term delivery. Obstet Gynecol 1985; 65:11-16.

19 Cox SM. Infection-induced preterm labor. In: Infections in pregnancy. Gilstrap LC, Faro S (eds). New York, Alz Rliss Inc, 1990: 247-53.

20 Brumfitt W. The effects of bacteriuria of pregnancy on maternal and fetal health. Kidney Int. 1975; 8(suppl.): 113-19.

21 Grio R, porpiglia M, Vetro E, uligini R, Piacentino R, Mini D, Marchino GL. Asymptomatic bacteriuria in pregnancy: maternal and fetal complications. Panminerva Med. 1994; 36: 198-200.

22 Risking death to give life. The World Health Report 2005.

23 Ahmed S, Khanum PA, Islam A. Maternal morbidity in rural Bangladesh: where do women go for care. ICDDR,B working paper. 1998, p 113.

24 Dey DK. Factors influencing maternal mortality in Bangladesh from a gender perspective. Department of Family Medicine, Umea University, Sweden Project paper, 1998. 